\title{
KEPEMIMPINAN KEPALA MADRASAH \\ DALAM MENINGKATKAN KEFEKTIFAN KINERJA GURU TERSERTIFIKASI DI MTs NU 02 GRINGSING KABUPATEN BATANG
}

\author{
NAFI'AN \\ Pengawas, Kantor Kementerian Agama Kabupaten Batang \\ e-mail:paknafian@gmail.com
}

\begin{abstract}
ABSTRAK
Kepala sekolah adalah pemimpin pendidikan yang mempunyai peranan sangat besar dalam mengembangkan kualitas pendidikan di sekolah. Berkembangnya semangat kerja, kerjasama yang harmonis, minat terhadap perkembangan pendidikan serta perkembangan kualitas guruguru yang dipimpinnya banyak ditentukan oleh kualitas pembinaan dan kepemimpinan kepala sekolah. Kepala sekolah juga melaksanakan pembinaan, memfasilitasi dan memberikan kesempatan yang luas serta semangat dan dorongan kepada para guru tersertifikasi. Hal ini juga bertujuan untuk dapat melaksanakan kegiatan pengembangan profesi melalui berbagai kegiatan pendidikan dan pelatihan (workshop). Pada penelitian ini peneliti menggunakan pendekatan deskriptif kualitatif. Pendekatan deskriptif kualitatif ini tidak selalu mencari sebab akibat namun lebih berupaya memahami situasi tertentu. Peneliti berusaha memahami dan menghayati peran kepemimpinan kepala madrasah dalam meningkatkan keefektifan kinerja guru tersertifikasi di MTs NU 02 Gringsing Kabupaten Batang. Penelitian ini juga menggunakan data sumber daya guru sebagai sumber utama yang hasil penelitiannya berupa kata-kata atau pernyataan yang sesuai dengan keadaan sebenarnya atau alamiah. Pelaksanaan proses implikasi kepemimpinan kepala madrasah, strategi kepemimpinan kepala madrasah mengantisipasi hambatan, hingga keberhasilan kepemimpinan kepala madrasah dalam meningkatkan keefektifan kinerja guru pada hakikatnya adalah tindakan dan kebijakan yang harus diambil kepala madrasah secara adil dan bijksana dalam rangka mengarahkan dan membantu guru untuk meningkatkan profesionalismenya. Sehingga pada akhirnya meraka akan manjadi sosok yang dihormati, disegani, memiliki kualifikasi yang memadai, wawasan dan skillnya terus meningkat serta menjadi panutan yang baik bagi peserta didik. Strategi kepemimpinan kepala MTs NU 02 Gringsing dalam melaksanakan evaluasi pembelajaran, terutama guru tersertifikasi juga berjalan baik. Hal ini dilakukan oleh kepala madrasah untuk mengamati langsung proses pembelajaran yang dilakukan oleh guru tersertifikasi mulai dari pra pembelajaran, kegiatan inti dan penutup pembelajaran. Setelah diadakan Supervisi dan evaluasi terhadap guru tersertifikasi di MTs NU 02 Gringsing baik berkaitan dengan pedagogik dan administrasinya, maupun kinerja guru tersertifikasi maka keefektifan kinerja para guru tersebut berjalan dengan baik.
\end{abstract}

Kata Kunci: Kepemimpinan, Kepala Madrasah, Kinerja Guru

\begin{abstract}
The principal was an educational leader who has a role in developing the quality of education in schools. The development of work spirit, harmonious cooperation, interest in the development of education, and the development of the quality of the teachers they lead were largely determined by the quality of coaching and leadership of the principal. The principal also carries out coaching, facilitating, and providing broad opportunities as enthusiasm and encouragement to certified teachers. It also aimed to carry out professional development activities through various educational and training activities. In this study, the researcher used a qualitative descriptive approach. This qualitative descriptive approach did not always look for cause and effect but sought to understand certain situations. Researchers tried to understand and appreciate the leadership role of the madrasa principal in increasing the effectiveness of certified teacher performance at MTs NU 02 Gringsing, Batang Regency. This study also used teacher resource data as the source whose research results are in the form of words or statements that are by actual or natural conditions. The implementation of the process of implicating the
\end{abstract}




\section{EDUCATIONAL : Jurnal Inovasi Pendidikan dan Pengajaran Vol. 2 No. 1 Februari 2022 e-ISSN : 2775-2593 | p-ISSN : 2775-2585}

leadership of the madrasah principal, the principal's leadership strategy in anticipating obstacles, to the success of the madrasah's leadership in increasing the effectiveness of teacher performance are essentially actions and policies that must be taken by the madrasah principal fairly and wisely to direct and assist teachers to improve their professionalism. So that in the end, they would become respected, respected figures, have adequate qualifications, their insights and skills continue to increase and become good role models for students. The leadership strategy of the head of MTs NU 02 Gringsing in carrying out learning evaluations, especially certified teachers, is also going well. It was done by the head of the madrasa to directly observe the learning process carried out by certified teachers starting from pre-learning, core activities, and closing lessons. After the supervision and evaluation of certified teachers at MTs NU 02 Gringsing, both related to pedagogy and administration, as well as the performance of certified teachers, the effectiveness of the teacher's performance went well.

Keywords: Leadership, Principal, Teacher Performance

\section{PENDAHULUAN}

Kepemimpinan merupakan salah satu pilar penting bagi perkembangan organisasi, karena pemimpinlah yang menggerakkan, merencanakan, mengorganisasikan dan mengawasi dinamika organisasi tersebut. Tanpa kehadiran pemimpin, organisasi tidak mungkin dapat tumbuh, berkembang dan berhasil dalam mencapai tujuannya. Dalam konteks inilah, posisi pemimpin menjadi sangat vital bagi organisasi, karena pemimpin merupakan salah satu pemersatu utama keberhasilan organisasi. Menurut Hasan (2017) kepemimpinan merupakan sebuah proses mempengaruhi seseorang dalam suatu organisasi/lembaga menuju tercapainya tujuan bersama. Dalam hal ini, kepemimpinan juga mempengaruhi interpretasi mengenai peristiwa-peristiwa para pengikutnya, pengorganisasian dan aktivitas-aktivitas untuk mencapai sasaran, memelihara hubungan kerjasama dan kerja kelompok, perolehan dukungan dan kerjasama dari orang-orang diluar kelompok atau organisasi. Pada posisi strategis seperti itu, keberhasilan suatu organisasi dapat dipandang sebagai representasi dari keberhasilan seorang pemimpin. Demikian pula sebaliknya, kegagalan organisasi/lembaga dalam mencapai tujuannya, merupakan representasi dari kegagalan seorang pemimpin dalam mengembangkan fungsi-fungsi kepemimpinannya.

Kepemimpinan dalam konteks pendidikan lebih menekankan kepada terjadinya hubungan antara personil sekolah serta menciptakan iklim kebersamaan dalam bekerja. Hal ini menciptakan hubungan yang harmonis diantara seluruh personil sekolah (Kepala Sekolah, Guru, Staf TU, Siswa dan lain-lain). Richard (2000: 125) mengemukakan terdapat dua prinsip kepemimpinan, prinsip pertama adalah adanya hubungan antara pemimpin dan pengikutnya. Prinsip kedua adalah pemimpin yang efektif menyadari dan mengelola secara sadar dinamika hubungan antara pemimpin dan pengikutnya. Dalam hal ini, kepemimpinan yang efektif membutuhkan kompetensi atau kemampuan untuk memotivasi orang lain untuk sejalan dengan arah pemikiran yang diinginkan seorang pimpinan. Kepala Sekolah adalah pemimpin pendidikan yang mempunyai peranan sangat besar dalam mengembangkan kualitas pendidikan di sekolah. Berkembangnya semangat kerja, kerjasama yang harmonis, minat terhadap perkembangan pendidikan serta perkembangan kualitas guru-guru yang dipimpinnya banyak ditentukan oleh kualitas pembinaan dan kepemimpinan kepala sekolah. Salah satu indikator keberhasilan sekolah adalah bila sekolah dapat mencapai target yang sesuai dengan visi dan misi sekolah dengan baik. Dalam kompetensi manajerial yang dimiliki oleh kepala sekolah, berbagai upaya direncanakan dan dijalankan guna peningkatan mutu pendidikan, salah satunya adalah dengan peningkatan proses belajar mengajar yang sangat tergantung kepada profesionalisme guru sebagai sumber daya manusia.

Sebuah definisi dari profesi menunjuk pada suatu pekerjaan atau jabatan yang menuntut keahlian tanggung jawab, dan kesetiaan terhadap pekerjaan itu. Sedangkan profesionalisme menunjuk pada derajat atau tingkat penampilan seseorang sebagai seseorang dalam menjalani profesinya tersebut (Lita: 2019). Guru yang dapat dikatakan profesional dalam menjalankan 
tugasnya sebagai pendidik harus memiliki kriteria khusus. Hal ini dalam upaya proses pembelajaran agar proses pendidikan dapat tercapai dengan maksimal. Sebagai bukti penghargaan kepada guru tersebut diberikan sertifikat guru profesional dan pemerintah Indonesia memberikan tunjangan profesi yang berlipat dari gaji yang diterima (Masnur: 2007). Peningkatan kinerja guru lewat program sertifikat profesi inilah sebagai upaya peningkatan mutu pendidikan. Rasionalnya adalah apabila kompetensi guru bagus yang diikuti dengan penghasilan bagus, diharapkan kinerjanya juga bagus. Apabila kinerjanya bagus maka pembelajaran juga bagus. Proses pembelajaran yang bagus, diharapkan dapat membuahkan hasil pendidikan yang bagus dan bermutu.

Sebagai guru profesional, maka akan tercermin dalam penampilan pengajaran dan dalam melaksanakan tugas-tugasnya yang ditandai dengan kemampuan serta ketrampilan dalam menggunakan teknologi yang dibutuhkan untuk kelancaran proses pembelajaran secara efektif dan efisien baik dalam materi maupun metodenya. Meskipun MTs NU 02 Gringsing sebagai lembaga pendidikan di bawah Kementerian Agama, dalam perjalanannya telah mengalami perkembangan, terbukti guru sertifikasi jumlahnya meningkat. Selain itu, sarana dan prasarana juga sebagai penunjang pembelajaran bertambah. Semua itu tidak lepas dari peran kepala dan pengawas madrasah dalam membina para guru di MTs NU 02 Gringsing,

Pada bidang pengembangan tenaga pendidik dan kependidikan terutama pada guru yang tersertifikasi, kepala madrasah sudah mengadakan berbagai usaha untuk meningkatkan kualitas profesionalismenya, diantaranya dengan mempengaruhi, membimbing, memotivasi dan mengadakan evaluasi kepada guru tersertifikasi, juga melalui diklat, penataran, workshop dan seminar. Namun berdasarkan observasi awal yang peneliti lakukan pada proses pelaksanaan pendidikan di MTs NU 02 Gringsing sampai saat ini masih ditemukan sebagian guru tersertifikasi yang belum melaksanakan tugasnya, seperti halnya tidak membawa perangkat pembelajaran waktu di kelas, tidak ada perhatian kepada siswa yang mengalami kesulitan belajar, kurang menumbuhkan motivasi belajar dan kurangnya menggunakan metode pembelajaran yang inovatif.

Salah satu bentuk kepemiminan kepala madrasah dalam meningkatkan kinerja guru tersertifikasi adalah melalui supervisi pembelajaran, yang pelaksanaannya perlu dilaksanakan secara terprogram dan sistematis, dimana tujuan utamanya adalah memberikan pembinaan kepada guru-guru tersebut, agar dapat melaksanakan tugasnya secara efektif dan efisien. Kepala madrasah juga melaksanakan pembinaan, memfasilitasi dan memberikan kesempatan yang luas serta semangat dan dorongan kepada para guru tersertifikasi. Hal ini juga bertujuan untuk dapat melaksanakan kegiatan pengembangan profesi melalui berbagai kegiatan pendidikan dan pelatihan yang dilaksanakan di madrasah, seperti MGMP, In House Trainning, dan kegiatan lainnya di luar madrasah (Mujtahid: 2009). Dalam hal ini, untuk menunjang kinerja guru diperlukan beberapa opsional kegiatan yang bisa dilaksanakan secara efektif dan bermanfaat bagi setiap guru. Berdasarkan pada pernyataan latar belakang tersebut, penelitian ini akan berfokus pada bagaimana saja pola kepemimpinan kepala madrasah dalam meningkatkan keefektifan kinerja guru tersertifikasi di MTs NU 02 Gringsing. Selanjutnya, penelitian ini juga akan menyajikan gambaran bagaimana kepemimpinan kepala madrasah dalam meningkatkan keefektifan kinerja guru yang tersertifikasi.

\section{METODE PENELITIAN}

Pendekatan penelitian ini menggunakan pendekatan deskriptif kualitatif, yaitu penelitian non hipotesis, sehingga dalam langkah penelitiannya tidak perlu merumuskan hipotesis. Penelitian ini menggunakan studi kasus untuk membahas tentang peran kepemimpinan kepala madsarah dalam meningkatkan keefektifan kinerja guru tersertifikasi di MTs NU 02 Gringsing. Hal ini tidak selalu mencari sebab akibat namun lebih berupaya memahami situasi tertentu. Peneliti berusaha memahami dan menghayati peran kepemimpinan kepala madrasah dalam meningkatkan keefektifan kinerja guru tersertifikasi. Penelitian ini telah dilaksanakan di MTs NU 02 Gringsing Kabupaten Batang Jawa Tengah, pada bulan Oktober 
s.d Nopember 2021 dan data dari sumber daya guru dan juga kepala sekolah merupakan sumber utama yang hasil penelitiannya berupa kata-kata atau pernyataan yang sesuai dengan keadaan sebenarnya atau alamiah. Peneliti juga menggunakan perspektif fenomenologis, yakni memahami dan menghayati peran kepemimpinan kepala madrasah dalam meningkatkan keefektifan kinerja guru tersertifikasi di madrasah. Setelah peneliti mengumpulkan data dari guru-guru dan kepala sekolah, kemudian peneliti melaksanakan evaluasi terhadap guru sertifikasi terkait kompetensi pedagogik guru, administrasi pembelajarann guru, dan penelitian kinerja guru di MTs NU 02 Gringsing.

\section{HASIL DAN PEMBAHASAN}

\section{Hasil Penelitian}

Dalam rangka peningkatan keefektifan kinerja guru tersertifikasi, kepala MTs NU 02 Gringsing melakukan peran, tindakan, cara-cara atau kiat khusus, inilah yang disebut strategi. Strategi peningkatan keefektifan kinerja guru tersertifikasi dilakukan kepala MTs NU 02 Gringsing bertujuan untuk menghasilkan dan membentuk guru tersertifikasi yang profesional dan bermutu tinggi yang memiliki komitmen kuat terhadap lembaga. Menurut Hidayanti (2021) kinerja guru masih menjadi sorotan terutama dalam hal menyiapkan rencana pembelajaran sampai tahap hubungan antar pribadi serta pemenuhan jumlah jam mengajar. Hal ini juga sebenarnya menjadi faktor penting bagaimana kepala sekolah bisa menstimulus kinerja guru. Ada beberapa tindakan yang dilakukan oleh pimpinan MTs NU 02 Gringsing yang berkaitan dengan kinerja guru tersertifikasi.

Berdasarkan dari hasil wawancara, dokumen dan observasi yang diperoleh peneliti bahwa implikasi meningkatkan keefektifan kinerja guru tersertifikasi dalam pembelajaran langkah yang ditempuh kepala madrasah adalah kemampuan dalam mempengaruhi, membimbing dan memotivasi para guru tersertifikasi, serta kemampuan mengevaluasi kinerja guru tersertifikasi. Rohimah (2021) juga mengemukakan sebagai pemimpin pendidikan, kepala madrasah bertanggung jawab untuk pertumbuhan guru secara terus menerus. Dengan praktek demokratis kepala madrasah mampu membantu guru untuk mengenal kebutuhan masyarakat sehingga tujuan pendidikan bisa memenuhi syarat tersebut. Dalam hal ini kepala madrasah selalu memberitahukan apa yang harus dikerjakan dan bagaimana cara mengerjakannya, memberi arahan penyelesaian tugas, melakukan pembinaan rutin pada guru, selalu berupaya memberikan solusi, dan selalu berupaya mengikutsertakan dalam pendidikan dan pelatihan.

Selanjutnya, menjadikan visi dan misi serta tujuan madrasah/lembaga sebagai target peningkatan keefektifan kinerja guru tersertifikasi. Visi MTs NU 02 Gringsing adalah suatu pandangan melihat suatu persoalan pendidikan baik dari segi cita-cita maupun dari segi teknik yang berkembang pada masa sekarang dan berlangsung secara berkesinambungan artinya MTs NU 02 Gringsing dalam pendidikan selalu berorientasi ke depan dengan melihat perubahan zaman. Sekolah tersebut juga berusaha membenahi kinerja unsur guru, karena bagaimanapun kinerja guru erat sekali dengan motto peserta didiknya, karena guru adalah orang yang terkait langsung dengan peserta didik. Dalam membenahi kinerja guru pihak pimpinan madrasah berupaya menjadikan visi misi tujuan lembaga sebagai arah dan target perkembangan mutu guru-gurunya. Adapun misi peningkatan kinerja guru di MTs NU 02 Gringsing adalah menjadikan guru profesional yang bermutu tinggi, yakni guru yang mampu mengantisipasi perubahan zaman, memiliki dedikasi, loyalitas, kreatifitas, dan keikhlasan untuk mengabdi kepada lembaga.

Dengan demikian uraian tentang visi misi tujuan peningkatan kinerja guru di MTs NU 02 Gringsing bila ditelaah lebih lanjut, bahwa misi utama peningkatan kinerja guru, untuk membentuk guru terampil yang memiliki dedikasi, loyalitas, dan komitmen yang tinggi terhadap lembaga yang mampu mengukir prestasi mempunyai keilmuan yang tinggi (IPTEK), dan memiliki kedalaman iman (IMTAQ). Hal ini berarti bahwa guru dituntut untuk selalu meningkatkan diri secara personal dan profesional guna menghadapi masa depan dengan bekal ilmu dan iman, untuk membawa anak didik ke jalan yang lebih baik. 
Dalam meningkatkan keefektifan kinerja guru tersertifikasi, kepala MTs NU 02 Gringsing mengadakan supervisi dan evaluasi secara transparan dan obyektif mutlak diperlukan, karena evaluasi merupakan kegiatan akhir dari proses dan tindakan manajemen kepemimpinan. Evaluasi atau penilaian terhadap guru biasanya lebih difokuskan pada prestasi individu guru terutama dalam proses kegiatan pembelajaran, dan peran sertanya dalam kegiatan pendidikan di madrasah. Kepala madrasah selalu bersikap obyektif dalam melakukan penilaian terhadap guru agar mudah untuk membina dan meningkatkannya. Sasaran penilaian terhadap guru yang dilakukan Kepala MTs NU 02 Gringsing adalah meninjau kembali catatan-catatan dalam kelas seperti prestasi dan perkembangan siswa, hasil tes, rencana pembelajaran.

Setelah peneliti mengumpulkan data yang bersumber dari kepala sekolah tersebut. Selanjutnya, peneliti mengadakan evaluasi kepada guru tersertifikasi untuk mengetahui dampak dari peran kepemimipnan kepala madrasah dalam meningkatan keefektifan kinerja guru tersertifikasi di MTs NU 02 Gringsing Kabupaten Batang.

Tabel 1. Hasil Nilai Penelitian Kompetensi Pedagogik Guru Tersertifikasi Di MTs NU 02 Gringsing

\begin{tabular}{|c|l|c|c|c|}
\hline No. & $\begin{array}{c}\text { Nama Guru } \\
\text { Terertifikasi }\end{array}$ & $\begin{array}{c}\text { Jumlah Skor } \\
\text { Nilai }\end{array}$ & $\begin{array}{c}\text { Nilai } \\
\text { Akhir }\end{array}$ & Kualifikasi \\
\hline 1 & Arifudin, S.Pd.I & 109 & 91 & $\mathrm{~A}$ \\
\hline 2 & Titik Mukti Aryanti, S.Pd & 109 & 91 & $\mathrm{~A}$ \\
\hline 3 & Ahmad Subaedi, S.Pd & 108 & 90 & $\mathrm{~A}$ \\
\hline 4 & Laili Fitriyati, S.Pd & 109 & 91 & $\mathrm{~A}$ \\
\hline 5 & Tri Fianah, S.Pd & 108 & 90 & $\mathrm{~A}$ \\
\hline 6 & Safril Bahar, S.Pd.I & 88 & 73 & $\mathrm{C}$ \\
\hline 7 & Ismiyati, S.Pd & 107 & 89 & $\mathrm{~A}$ \\
\hline 8 & Ahmad Rosidin, S.Pd & 109 & 91 & $\mathrm{~A}$ \\
\hline 9 & Muarifudin, S.Pd & 90 & 75 & $\mathrm{~B}$ \\
\hline
\end{tabular}

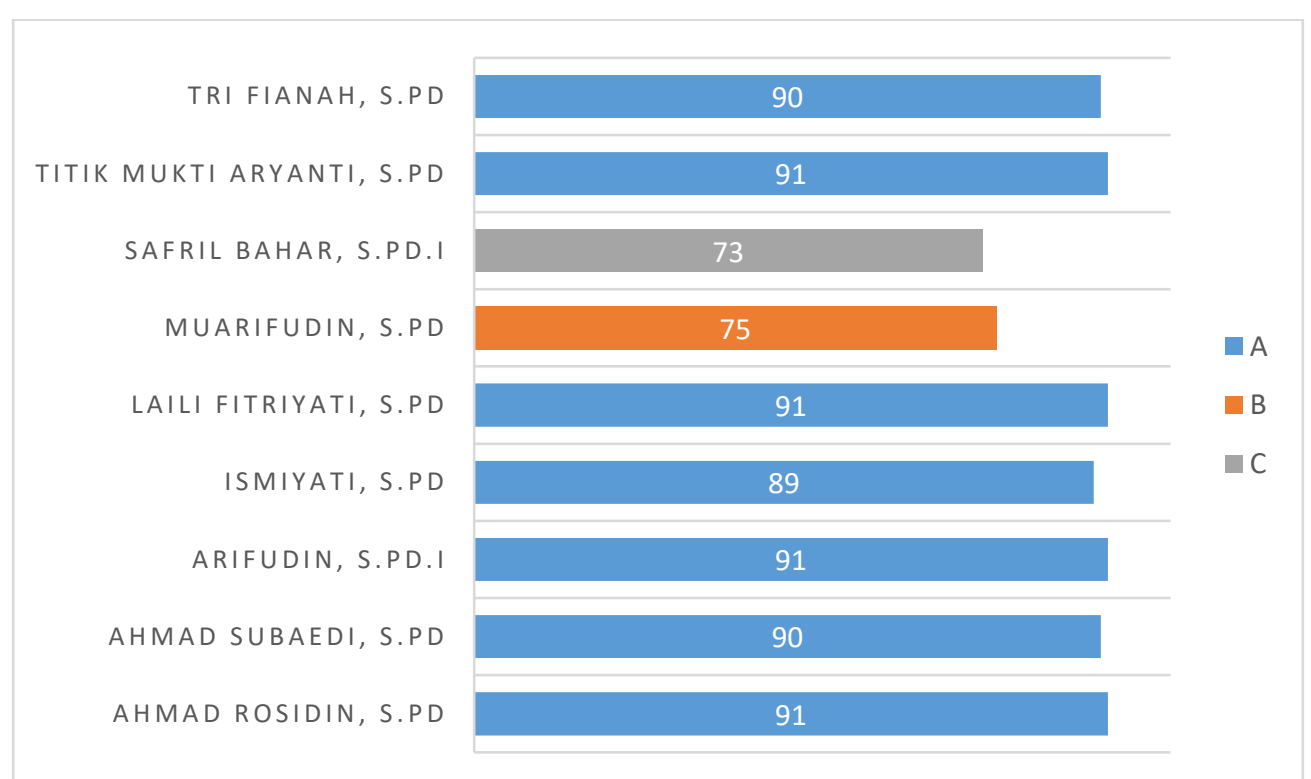

Gambar 1. Grafik Hasil Kompetensi Pedagogik Guru Tersertifikasi

Acuan Penilaian :

A. $81-100=$ Amat baik

B. $75-80=$ Baik

C. $55-74=$ Cukup

D. $40-54=$ Kurang

E. $0-39=$ Jelek 
Dari uraian tabel Hasil nilai penelitian diatas jelaslah bahwa penilaian kompetensi pedagogik guru tersertifikasi di MTs NU 02 Gringsing, dari 9 guru tersertifikasi yang mempunyai nilai Amat Baik berjumlah 7 Orang (77,78 \%), yang mempunyai nilai Baik berjumlah 1 orang $(11,11 \%)$, dan yang mempunyai nilai Cukup berjumlah 1 orang $(11,11 \%)$. Ini berarti bahwa secara umum kompetensi pedagogik para guru tersertifikasi di MTs NU 02 Gringsing adalah Amat Baik, yaitu mencapai 7 Orang atau 77,78 \%.

Tabel 2. Hasil Nilai Penelitian Administrasi Pembelajaran Guru Tersertifikasi Di MTs NU 02 Gringsing

\begin{tabular}{|c|l|c|c|c|}
\hline No. & $\begin{array}{c}\text { Nama Guru } \\
\text { Tersertifikasi }\end{array}$ & $\begin{array}{c}\text { Jumlah } \\
\text { Skor Nilai }\end{array}$ & $\begin{array}{c}\text { Nilai } \\
\text { Akhir }\end{array}$ & Kualifikasi \\
\hline 1 & Arifudin, S.Pd.I & 2180 & 91 & A \\
\hline 2 & Titik Mukti Aryanti, S.Pd & 2180 & 91 & A \\
\hline 3 & Ahmad Subaedi, S.Pd & 2180 & 91 & A \\
\hline 4 & Laili Fitriyati, S.Pd & 2180 & 91 & A \\
\hline 5 & Tri Fianah, S.Pd & 2160 & 90 & A \\
\hline 6 & Safril Bahar, S.Pd.I & 1740 & 72,5 & C \\
\hline 7 & Ismiyati, S.Pd & 2160 & 90 & A \\
\hline 8 & Ahmad Rosidin, S.Pd & 2180 & 91 & A \\
\hline 9 & Muarifudin, S.Pd & 1840 & 77 & B \\
\hline
\end{tabular}

HASIL NILAI ADMINISTRASI

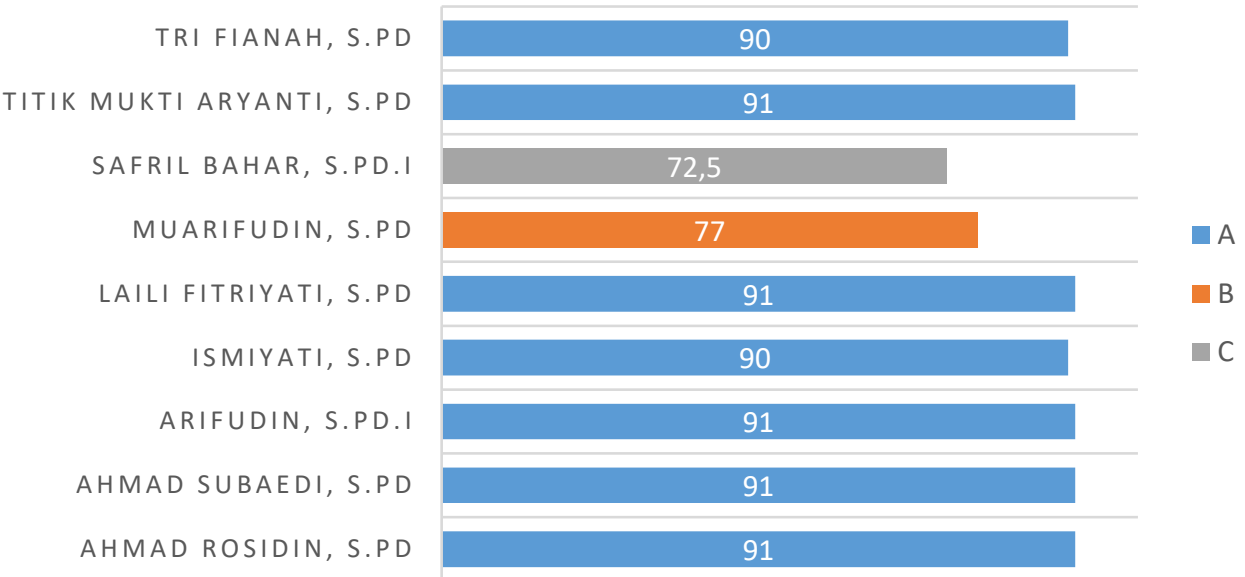

\section{Gambar 2. Grafik Hasil Kompetensi Administrasi Pembelajaran Guru Tersertifikasi}

Acuan Penilaian :

A. $81-100=$ Amat baik

B. $75-80=$ Baik

C. $55-74=$ Cukup

D. $40-54=$ Kurang

E. $0-39=$ Jelek

Dari hasil nilai penelitian Administrasi Pembelajaran para guru tersertifikasi di MTs NU 02 Gringsing Kab. Batang diatas adalah bahwa yang mempunyai nilai Amat Baik berjumlah 7 Orang $(77,78 \%)$, yang mempunyai nilai Baik berjumlah 1 Orang $(11,11 \%)$, dan yang mempunyai nilai Cukup ada 1 Orang $(11,11 \%)$. Dengan demikian secara umum administrasi pembelajaran para guru tersertifikasi di MTs NU 02 Gringsing masih dikategorikan Amat Baik, yaitu mencapai 7 Orang atau 77,78 \%. Hasil ini amat signifikan dengan hasil pelaksanaan 
Akreditasi MTs NU 02 Gringsing tahun 2011 yang mencapai nilai 96 dengan kualifikasi nilai A.

Tabel 3. Hasil Penelitian Penilaian Kinerja Guru Tersertifikasi Di MTs NU 02 Gringsing

\begin{tabular}{|c|l|c|c|c|}
\hline No. & $\begin{array}{c}\text { Nama Guru } \\
\text { Tersertifikasi }\end{array}$ & $\begin{array}{c}\text { Jumlah } \\
\text { Skor Nilai }\end{array}$ & $\begin{array}{c}\text { Nilai } \\
\text { Akhir }\end{array}$ & Kualifikasi \\
\hline 1 & Arifudin, S.Pd.I & 50 & 89 & A \\
\hline 2 & Titik Mukti Aryanti, S.Pd & 50 & 89 & A \\
\hline 3 & Ahmad Subaedi, S.Pd & 49 & 87 & A \\
\hline 4 & Laili Fitriyati, S.Pd & 50 & 89 & A \\
\hline 5 & Tri Fianah, S.Pd & 48 & 86 & A \\
\hline 6 & Safril Bahar, S.Pd.I & 38 & 68 & C \\
\hline 7 & Ismiyati, S.Pd & 47 & 84 & B \\
\hline 8 & Ahmad Rosidin, S.Pd & 48 & 86 & A \\
\hline 9 & Muarifudin, S.Pd & 43 & 77 & B \\
\hline
\end{tabular}

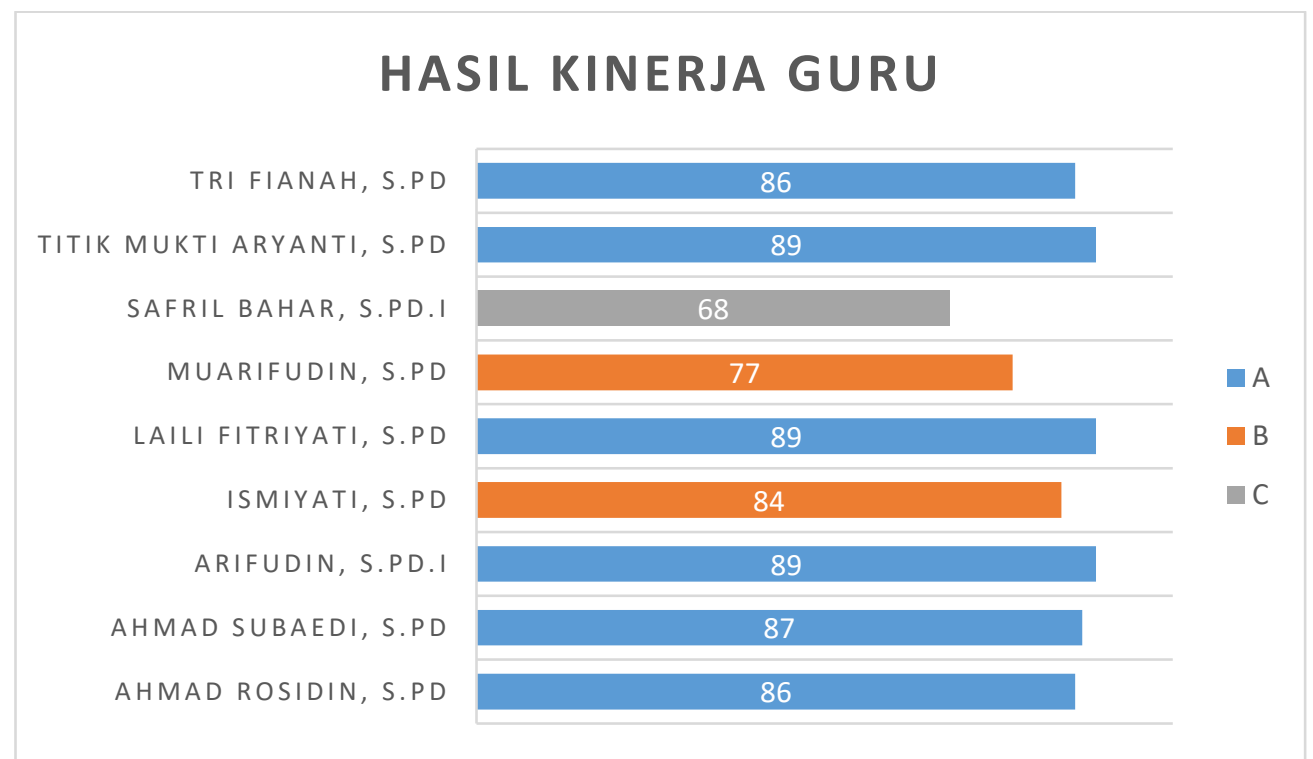

Gambar 3. Grafik Hasil Penilaian Kinerja Guru Tersertifikasi

Acuan Penilaian :

A. $81-100=$ Amat baik

B. $75-80=$ Baik

C. $55-74=$ Cukup

D. $40-54=$ Kurang

E. $0-39=$ Jelek

Dari hasil penelitian penilaian kinerja guru tersertifikasi di MTs NU 02 Gringsing diatas adalah bahwa yang mempunyai nilai Amat Baik berjumlah 6 Orang $(66,67 \%)$, yang mempunyai nilai Baik berjumlah 2 Orang (22,22\%), dan yang mempunyai nilai Cukup ada 1 Orang $(11,11 \%)$. Dengan demikian secara umum penilaian kinerja para guru tersertifikasi di MTs NU 02 Gringsing masih dikategorikan Amat Baik, karena dapat mencapai 6 Orang atau $66,67 \%$. Atau $2 / 3$ orang dari 9 orang guru tersertifikasi.

\section{Pembahasan Hasil Penelitian}

Berdasarkan keterangan dari hasil penelitian, pengawasan dan evaluasi pendidikan dapat diartikan sebagai salah satu kegiatan untuk mengetahui realisasi perilaku personel dalam organisasi dan apakah tingkat pencapaian tujuan pendidikan sesuai dengan yang dikehendaki, 
kemudian apakah perlu diadakan perbaikan. Pengawasan dilakukan untuk mengumpulkan data tentang penyelenggaraan kerjasama antar guru, kepala madrasah, konselor, supervisor, dan petugas madrasah lainnya dalam institusi satuan pendidikan. Pada dasarnya ada tiga langkah yang perlu ditempuh dalam melaksanakan pengawasan, yaitu (1) menetapkan alat ukur atau standar, (2) mengadakan penilaian atau evaluasi, dan (3) mengadakan tindakan perbaikan atau koreksi dan tindak lanjut. Oleh sebab itu, tindakan pengawasan itu dimaksudkan untuk mencegah penyimpangan dalam pelaksanaan pekerjaan, menilai hasil kegiatan dan sekaligus melakukan tindakan perbaikan (Purwanto, 2004).

Atas pertimbangan inilah Kepala MTs NU 02 Gringsing menetapkan berbagai metode dan sistim penilaian dalam melaksanakan proses peningkatan keefektifan kinerja guru pada tahap akhir yaitu pada bagaian evaluasi dan pengawasan. Sistim atau metode-metode yang dipakai adalah dilakukannya supervisi pendidikan. Secara umum supervisi dapat dimaknai atas dasar keseluruhan aktivitas yang dilakukan secara individu maupun kelompok sesuai dengan tujuan masing-masing terhadap personil, kelompok ataupun terhadap suatu program dalam berbagai bidang kependidikan. Sedangkan teknik yang digunakan Kepala MTs NU 02 Gringsing dalam melakukan evaluasi atau penilaian dan menggunakan supervisi adalah teknik kunjungan kelas/observasi kelas, percakapan personal dan supervisi kelompok, dalam melakukan supervisi pendidikan, Kepala MTs NU 02 Gringsing menggunakan pendekatan secara langsung (directive) dan secara tidak lansung (non directive). Berkaitan dengan penilaian kinerja guru ini, sesuai dengan Peraturan Mendiknas Nomor 16 tahun 2007 bahwa berbagai standard kompetensi guru yaitu antara lain :

Kompetensi Paedagogik

(1) Menguasai karakteristik peserta didik dari aspek fisik, moral, social, cultural, emosional dan intektual, (2) Menguasai teori belajar dan prinsip-prinsip pembelajaran yang baik, (3) Mengembangkan kurikulum yang terkait dengan mata pelajaran/bidang pengembangan yang diampu, (4) Menyelenggarakan pembelajaran yang memndidik, (5) Memanfaatkan teknologi informasi dan komunikasi untuk kepentingan pembelajaran, (6) Memfasilitasi pengembangan potensi peserta didik untuk mengaktualisasikan berbagai potensi yang dimiliki, (7) Berkomunikasi secara efektif, empatik, dan santun dengan peserta didik, (8) Menyelenggarakan penilaian dan evaluasi proses dan hasil belajar, (9) Memanfaatkan hasil penilaian dan evaluasi untuk kepentingan pembelajaran, dan (10) Melakukan tindakan reflektif untuk peningkatan kualitas pembelajaran.

Kompetensi kepribadian

(1) Bertidak sesuai dengan norma agama, hokum, social dan kebudayaan nasional Indonesia, (2) Menampilkan diri sebagai pribadi yang jujur, berakhlak mulia, dan teladan bagi peserta didik dan masyarakat, (3) Menampilkan diri sebagai pribadi yang mantap, stabil, dewasa, arif dan berwibawa, (4) Menunjukkan etos kerja, tanggungjawab yang tinggi, rasa bangga menjadi guru, dan rasa percaya diri, dan (5) Menjunjung tinggi kode etik profesi guru. Kompetensi Sosial

(1) Bersikap inklusif, bertindak objektif, serta tidak diskriminatif karena pertimbangan jenis kelamin, agama, ras, kondisi fisik, latar belakang keluarga, dan status social ekonomi, (2) Bekomunikasi secara efektif, empatik, dan santun dengan sesama pendidik, tenaga kependidikan, orang tua dan masyarakat, (3) Beradaptasi di tempat tugas di seluruh wilayah Republik Indonesia yang memiliki keragaman sosial budaya, dan (4) Berkomunikasi dengan komunitas profesi sendiri dan profesi lain secara lisan dan tulisan atau bentuk lain.

Kompetensi Profesional

(1) Menguasai materi, struktur, konsep, dan pola piker keilmuan yang mendukung mata pelajaran yang diampu, (2) Menguasai standard kompetensi dan kompetensi dasar nata pelajaran/bidang pengembangan yang diampu, (3) Mengembangkan materi pembelajaran yang diampu secara kreatif, (4) Mengembangkan keprofesionalan secara ber-kelanjutan dengan melakukan tindakan reflektif, dan (5) Memanfaatkan teknologiinformasi dan komunikasi untuk berkomunikasi dan mengembangkan diri. 
Kepala MTs Nu 02 Gringsing Kab. Batang dalam melakukan penilaian terhadap perkembangan dan kinerja guru selain menggunakan supervisi pendidikan, juga melakukan penilaian dengan menggunakan format penilaian yang sudah dibakukan oleh pemerintah yang dikenal dengan Daftar Penilaian Kinerja (DP3). Sistem penilaian yang dilakukan oleh kepala MTs NU 02 Gringsing dalam menilai guru yaitu supervisi dan daftar penilaian kinerja guru menurut analisis penulis mempunyai nilai positif dan negatif. Penilaian menggunakan dengan supervisi mempunyai nilai positif karena disamping melakukan penilaian terhadap kondisi dan perkembangan guru, supervisi juga dapat membantu guru yang sedang mengalami kesulitan, oleh karena itu, kepala madrasah sebagai seorang evaluator dan supervisor dapat mebantu mengatasi kesulitan-kesulitan yang dihadapi oleh guru. Sistem evaluasi yang berdasarkan visi, misi, dan tujuan madrasah dapat membantu kepala madrasah untuk mengevaluasi dan menilai obyektifitas guru baik dari segi kuantitas dan kualitas. Oleh karena itu kedua sistem penilaian tersebut diatas dapat dikolaborasikan sehingga ada proses keseimbangan dalam proses penilaian, dan dapat menjadi feedback untuk program peningkatan keefektifan kinerja guru selanjutnya.

Kepala MTs NU 02 Gringsing melaksanakan kegiatan peningkatan keefektifan kinerja guru mulai dari proses strategi kepemimpinan kepala madrasah dalam meningkatkan keefektifan kinerja guru tersertifikasi, Hambatan-hambatan dan upaya mengatasinya terhadap peningkatan kinerja guru tersertifikasi, hingga implikasi kepemimpinan kepala madrsah dalam meningkatkan keefektifan kinerja guru tersertifikasi, selalu mengutamakan kerjasama tim yang solid. Hampir tidak ditemukan dalam setiap proses dan tahapan peran kepemimpinan yang dilakukan oleh kedua kepala MI tersebut dikerjakan sendiri oleh kepala madrasah, baik dalam proses strategi kepemimpinan kepala madrasah, upaya kepala madrasah mengantisipasi hambatan, hingga implikasi kepemimpinan kepala madrasah yang diperoleh dalam meningkatkan keefektifan kinerja guru tersertifikasi. Kepala madrasah selalu melibatlkan seluruh civitas akademika termasuk para guru, dan wakil kepala madrasah. Karena guru merupakan unsur penting dalam lembaga pendidikan yang paling mengetahui dan mengerti terhadap persoalan yang dihadapinya dalam melaksanakan tugas utamanya sebagai pendidik, guru merupaka orang yang terjun langsung dalam proses kegiatan belajar mengajar di madarsah. Kedua kepala MI ini berhasil membina hubungan yang harmonis dengan guru, memberikan apresiasi, dan empati terhadap para guru.

Dari hasil penelitian kompetensi kepemimpinan kepala madrasah, dalam meningkatkan keefektifan kinerja guru tersertifikasi di MTs NU 02 gringsing, dapat peneliti simpulkan bahwa kompetisi kepemimpinan kepala madrasah menjadi faktor determinan dalam proses peningkatan kefektifan kinerja guru, disamping itu, pelaksanaan proses implikasi kepemimpinan kepala madrasah, strategi kepemimpinan kepala madrasah mengantisipasi hambatan, hingga keberhasilan kepemimpinan kepala madrasah dalam meningkatkan keefektifan kinerja guru. Menurut Nabila (2018) kepala madrasah merupakan satu komponen pendidikan yang paling berperan dalam meningkatkan kualitas pendidikan dan bisa dikatakan keberhasilan suatu lembaga bergantung pada kepemimpinan kepala sekolahnya. Pada hakikatnya adalah tindakan dan kebijakan yang harus diambil kepala madrasah secara adil dan bijksana dalam rangka mengarahkan dan membantu guru untuk meningkatkan profesionalismenya. Sehingga pada akhirnya meraka akan manjadi sosok yang dihormati, disegani, memiliki kualifikasi yang memadai, wawasan dan skillnya terus meningkat serta menjadi panutan yang baik bagi peserta didik.

\section{KESIMPULAN}

Strategi kepemimpinan kepala MTs NU 02 Gringsing dalam melaksanakan evaluasi pembelajaran, terutama guru tersertifikasi juga berjalan baik. Hal ini dilakukan oleh kepala madrasah untuk mengamati langsung proses pembelajaran yang dilakukan oleh guru tersertifikasi mulai dari pra pembelajaran, kegiatan inti dan penutup pembelajaran. Kegiatan ini dilakukan kepala madrasah untuk mendapatkan informasi secara langsung tentang berbagai hal 
yang berkaitan dengan profesionalisme guru dalam melaksanakan pembelajaran, sehingga kepala madrasah dan guru dapat mendiskusikan berbagai permasalahan yang ditemukan mencari jalan keluar dan menyusun program untuk masa yang akan datang. Visi, misi dan tujuan lembaga MTs NU 02 Gringsing selalu dijadikan target peningkatan keefektifan kinerja guru tersertifikasi supaya kemajuan lembaga pendidikan tersebut dapat berkembang sesuai profil madrasah, dan sesuai dengan perkembangan zaman.

Setelah diadakan Supervisi dan evaluasi terhadap guru tersertifikasi di MTs NU 02 Gringsing baik berkaitan dengan pedagogik dan administrasinya, maupun kinerja guru tersertifikasi maka keefektifan kinerja para guru tersebut berjalan dengan baik. Bukti Keefektifan Kinerja guru tersertifikasi di MTs NU 02 Gringsing ini sudah berjalan dengan baik juga dapat dilihat bahwa para guru di MTs NU 02 Gringsing selalu melaksanakan tugas degan tepat waktu yang telah ditentukan, juga senantiasa berusaha mencapai tujuan madrasah secara tepat, dan selalu mengusahakan bekerja sesuai dengan peraturan kerja yang berlaku di Madrasah. Walaupun memang masih ada sebagian guru di MTs NU 02 Gringsing yang secara kinerja kurang menunjukkan sebagai guru yang professional.

\section{DAFTAR PUSTAKA}

Arikunto, Suharsimi, 2010, Prosedur Penelitian Suatu Pendekatan Praktek, Jakarta : Rineka Cipta

Baharun, H. (2018). Peningkatan kompetensi guru melalui sistem kepemimpinan kepala madrasah. At-Tajdid: Jurnal Ilmu Tarbiyah, 6(1), 1-26.

Beckhard, R. 2000. The leader of the Future. Jakarta: Gramedia

Hidayanti, N. (2021). Analisis Gaya Kepemimpinan Kepala Sekolah Dalam Meningkatkan Kinerja Guru Di SMPN 3 Pelaihari. Proceeding: Islamic University of Kalimantan.

Latiana, L. (2019). Peran Sertifikasi Guru Dalam Meningkatkan Profesionalisme Pendidik. Edukasi, 13(1).

Muslich, M. 2007. Sertifikasi Guru Menuju Profesionalisme Pendidik, Jakarta: Bumi Aksara Mujahid, 2009, Pengembangan Profesi Guru, Malang : UIN-Malang Press

Nabila, I. (2018). Kompetensi Supervisi Kepala Madrasah. Jurnal Isema: Islamic Educational Management, 3(1).

Purwanto, N. 2004. Prinsip-Prinsip dan Teknik Evaluasi Pengajaran. Bandung : Rosdakarya

Rohimah, N. (2021). Peran Kepala Madrasah Dalam Meningkatkan Mutu Pendidikan Agama Islam Di Mts Negeri 1 Paser. Journal of Innovation Research and Knowledge, 1(5), 867-876.

Sukmadinata, Syaodih, \& Nana. 2009. Metode penelitian Pendidikan. Bandung: Remaja Rosdakarya 